\title{
Web-Technologies and Multimedia Systems in the Training of Professionals in the Education System
}

\author{
Alona Korol \\ Postgraduate education \\ Mykola Yarmachenko Institute of \\ Special Pedagogy and Psychology of \\ the National Academy of \\ Pedagogical Sciences of Ukraine \\ Kiev, Ukraine \\ akorolin@gmail.com \\ Anna Khilya \\ Department of Primary Education \\ Vinnytsia Mykhailo Kotsiubynskyi \\ State Pedagogical University \\ Vinnytsia, Ukraine \\ anika.line@gmail.com
}

Abstract - Contemporary technologies of training specialists in different professions envisage mastering the skills of a 'quality user' of computer technologies. At the same time, the issues of training primary school teachers, specialists in inclusive and remedial education to use more complex multimedia systems with the need to understand programming processes have often been excluded from basic courses as an 'unnecessary' component.

But considering the current trends towards distance education, the "rejuvenation" of 'advanced users' and the need to maintain a educator's reputation, the trend towards introducing such systemic courses in the training process for specialists in primary, inclusive and correctional education has become a kind of concept for professional competence. It was based on the needs of today's teachers to transfer knowledge through multimedia systems (creating interactive databases, web pages, blogs or websites, preparing and conducting WebQuests, using computer games from producers or their own development through the platforms Wordwall, Etreniki, Flippity and Scratch programmes, etc.) that became the deciding factor for introducing specific topics on their use into training courses and expanding basic programmes of computer competency. Also, the training process began to include interaction with the training audience through social media. This multi-component work to develop a «modern/advanced» teacher provides the basis

\author{
Viktoriia Kravchenko \\ Department of Special Pedagogy and \\ Special Psychology \\ Municipal Institution of Higher \\ Education «Khortytsia National \\ Educational and Rehabilitation \\ Academy» of Zaporizhzhya Regional \\ Council \\ Zaporizhzhya, Ukraine \\ info@khnnra.zp.ua
}

not only for improving the quality of the educational process, but also for its individualization according to the needs of each participant and his/her special educational needs, allowing to change the complexity of tasks, the saturation of tasks with audiovisual information.

Keywords - high school, informatization, social networks, web-technologies, multimedia systems, teacher training, special educational needs.

\section{INTRODUCTION}

It is impossible to imagine the modern world and society without technology. They meet us at every stage of our lives, in professional activities. And in connection with the events of 2019 - technology "got» in the structure of the educational process.

After all, education itself in the classroom-lesson system has existed for over 240 years. And it has been particularly difficult to change these processes in the training of specialists in the humanities - elementary school teachers, remedial teachers, and other professions related to the education of the younger generation.

It is also worth noting that within the framework of the New Ukrainian School (NUSH) reform we need to focus

\section{Online ISSN 2256-070X


on the formation of children's and teachers' information and digital competence as one of the priorities within the ten core competencies spelled out in the basic documents of NUSH.

Thus, according to the terminology, the concept of information and digital competence consists of confident and at the same time critical use of information and communication technologies to create the search, processing, exchange of information at work, in the public sector and in personal communication. In addition, the ethical issues of working with information (copyright, intellectual property, etc.) and basic skills (information and media literacy, basic programming, algorithmic thinking, robotics with databases, Internet security skills, cybersecurity) are separately prescribed, which will fully allow the individual to be «in flow» with the modern trends of society and all areas of human activity [1].

In this important role played by the human ability to form connections necessary to achieve online transmission of multimedia information, as well as to share resources, forming an ideal multimedia network environment and because multimedia is a combination of text, graphics, animation, video, sound, special effects, etc.; contains infinite space imagination, we not only change the learning and understanding of the issue, but also change the way information is distributed [2]. Which is very important to ensure effective Among the features of new multimedia are: Integration; Nonlinear characteristics of Non - linear; Nonlinear characteristics of Non - linear; Real-time; Edit ability; Ease of the use of information [2]. In addition, all this we need to consider when developing and preparing materials for teaching disciplines for future teachers.

In addition, our study was based on certain aspects proposed by the global scientific community as practices to change and improve the quality of the presentation of lecture and practical material in the educational process. For example, we took advantage of theoretical developments in terms of using films to teach inclusive education technologies through ease of perception and the corresponding perception of usefulness, as well as the adoption of the main messages of the proposed discipline [3].

In addition, the selection and refinement of the presentation of certain topics, especially those related to speech therapy issues, was influenced by research based on differences in learning processes and outcomes of using multimedia systems with / without the addition of audio; the impact of such materials in teaching children with speech development problems and for their typically developing peers [4].

A separate part of our work was to use the study's work with manipulations and effects:

- from studying and testing with text and images;

- learning with text and images, but testing with text only;

- text-only learning and text-and-image testing;

- text-only learning and text-testing [5].
It was important to use the developments of the project, which considered the development of computer technology for two diametrically opposed groups of children (children with autism and children with Down syndrome). As well as the results obtained by the researchers on the inexpediency of using the same multimedia learning system due to the differences in perception and processing of information by these categories of children [6].

In addition, we were also able to note some of the benefits of multimedia applications for teaching and learning described in research projects. Such as the ability to transform abstract concepts into concrete content; the ability to present large amounts of information in a limited amount of time with less effort; the ability to stimulate students' interest in learning and giving the teacher the opportunity to know the students' position in learning [7]. All these components quite strongly influence the construction of the learning process, the selection of the proposed material and, very importantly, the ability to follow the individual characteristics of each participant in the learning process and taking into account the dynamics of the group.

It was these changes that allowed us to take more seriously the training of future professionals to use web technologies and multimedia systems in practice.

Thus, to understand the current situation, we identified as the main goal of the proposed report - the rationale for the use and practical training of non-technical professionals to use web technologies and multimedia systems in professional activities. In this regard, we identified the following tasks for this report:

1. Analyze work programs of ICT teaching for nontechnical specialties (elementary school teacher, preschool teacher, inclusive class teacher, remedial educator, etc.).

2. To analyze practicing teachers' and students' awareness of the possibilities and practices of using web technologies and multimedia systems in the educational process.

3. To outline the main problems of the introduction and use of such technologies in the daily practice of teachers.

\section{MATERIALS AND METHODS}

In our study, which originally focused on «Features of the use of ICT in Speech Therapy Practice of Preschool Institutions» and was conducted in 2017-2018, we investigated the awareness of practicing speech therapists (20 focus group participants) in organizing consultations and presentation of work experience using web technologies [8]. The results of the professional development can be found in the previous article.

Further, the study was expanded and revised in the context of the organization of the educational process 2019-2020. It consisted of the work within the study of disciplines of inclusive education with the use of multimedia systems and web technologies in the process of presenting information. Also from the organization of independent work of students (64 participants of the focus 
group). The results of the research will be presented soon in a separate publication on «Inclusive Practices in Distance Education: Challenges and Necessity».

To date, we continue to conduct an in-depth study for the 2020-2021 academic year. This is the third phase to examine the impact of distance learning on the outcomes of the educational process within the disciplines of the inclusive cycle and the subsequent professional engagement of graduates. As part of this phase, we engaged 60 participants. Part of the respondents - 19 students are elementary school teachers and teaching assistants, who receive additional education in the specialty «Inclusive Education» and 41 respondents - inpatient students, who receive the first specialty bachelor's degree.

As the experiment is ongoing, in this report we present the results of the ascertaining experiment, which consisted of surveys, questionnaires, and interviews of engaged respondents.

\section{RESULTS AND DISCUSSION}

Thus, at the first stage of our research in the format of this report, we started from the issues of training nontechnical specialties, such as teachers of elementary school, educators of pre-school institutions, remedial teachers, specialists of inclusive education, which are in the public domain. We took as a basis the existing training programs: «Information and communication technologies in elementary school» (Lutsk, 2015) [9], «Information technologies in special education» (Kiev, 2019) [10], «Information technologies in inclusive education of children with developmental and socialization complications» (Ivano-Frankivsk, 2019)» [11], «Information and communication technologies in scientific research» (Vinnitsa, 2019) [12]. It is important to note that only one of them is a compulsory discipline [12], and the others are elective. What all of these programs have in common:

- a theoretical part on the development of ICT;

- theoretical part on basic terminology and positive and negative aspects of ICT usage in educational practice;

- elements of computer literacy and familiarity with software;

- introduction to different services (Microsoft Office Word, Excel, Access, PowerPoint; Google Cloud Services).

But what is important is that, in fact, most students already use these products every day. Of course, they may not know the «official» name of this or that product, but everyone can understand and be a confident user today.

It is worth noting that in the training of specialists of a wide range of specialties quite a big emphasis is placed on:

- The study of theoretical material;

- Familiarity with various projects operating in Ukraine (mainly for high school - graduating classes, as well as students);

- Methods of preparing and conducting web classes;
- Technology WikiWiki;

- Issues of using electronic educational and methodological complexes of disciplines.

The distinctive features of the other programs is a narrow focus and the selection of each of the areas of training necessary to implement in professional activities the most appropriate models of use of multimedia systems and web-based technologies.

So, for elementary school teachers and educators use the familiarity and hands-on development of assignments using KSU Feedback, Windows Movie Maker [9].

For special educators (remedial educators, rehabilitation teachers, teachers, defectologists, speech therapists) demonstrate the possibilities of working with the application InShot, Padlet virtual interactive whiteboard, Web-services to create intelligent maps, charts, infographics, online video editors, images, animation, Canva, Crello, UGC-hosting, online community «Parents SOS», etc [10]. Special technical devices and programs for working with children with different nosologies also deserve special attention in this course. But the questions of studying and actually using them are often hindered by problems of financing. That is why the study is done in words and on the basis of the description of the products offered, such as «handheld computer» (ChatPC), «Talking mittens», special bracelets, programs of the hearing and speech complex «Communication», communicators, multifunctional device «Tango», speech training simulator «Delfa-142. 1», training and software complex «Adaptation-Logo», computer program «zaikanie.net», hearing and speech complex «Live sound», simulator «World of Sounds», program «Games for Tigra», etc. In rare cases of highquality cooperation with specialized centers, medical institutions, public or private organizations, students can get acquainted with them in reality.

In the issues of training specialists in inclusive education and developing their information and digital competence, one can see a targeted focus on studying the characteristics of children and a lack of clear recommendations for the study of ICT proper, which can, should and must be used in the work with children with special educational needs.

At the same time, it is worth noting that the quarantined limitations of offline learning have led to improvements in the educational process. The use of multimedia systems and web technologies. This was also reflected in changes in the program of elective disciplines. Thus, in Vinnitsa State Pedagogical University named after Mykhailo Kotsyubinsky today for the specialties Elementary School, Pre-school Education, Inclusive education offers one compulsory educational discipline of professional training cycle («Information and communication technologies in the organization of the educational process in institutions of pre-school education and elementary school») and five elective subjects ( «LMS Methods of development and use of electronic resources», «Digital innovation technology», 
«WEB-programming», «Fundamentals of WEB-design» and «Management of distance learning product»). Although some programs are in closed access, we can note improvements in the training of non-technical specialists, which allows the teacher to be «on equal footing» with confident users - which are modern children.

Continuing to consider the results of our study, we concluded that, due to several factors, distance learning allowed teachers to «recognize» the need to improve the quality of work and the use of web technologies and multimedia systems in the educational process.

So, before the beginning of our experiment, we conducted a questionnaire followed by an interview with 60 participants in the experiment. Among the questions that we asked the participants we can note the most important for us in blocks:

- General information;

- Basic level information on mastery and understanding of web technologies and multimedia systems;

- Information on the use of educational programs and applications with programming elements for educational purposes;

- Information on the use, as well as the desire to learn to use more complex designs in the form of web quests and programs with game development based on basic programming elements.

On the basis of the questionnaire, as well as to develop and refine the next stages of our work, we identified four levels of information and digital competence:

- high - possession of basic skills of using and creating online presentations, videos, knowledge and understanding of web quest technologies, practical use of various platforms to create educational games Wordwall, Etreniki, Flippity and more serious programming elements - Scratch;

- intermediate - almost identical to high, but without the ability to create sites and use software with programming elements

- sufficient - the student has the skills to create online presentations, uses web technologies and multimedia systems, but is not familiar with the process of their creation;

- low - the level of technology does not allow the student to use «blanks» to create an interactive, connect to the questionnaire without outside help, and create presentations and videos.

The result of the survey was that some respondents showed a high level of proficiency in the proposed set of technologies - they already had skills in creating web quests, materials on the Scratch platform. There were $20 \%$ of such students (12 people). However, during the interview it was determined that 8 people chose these items because they had heard that other professionals use something similar, looked at the Internet during the questionnaire, or took the name as work with scratch cards, scratch map of the world, where it is necessary to erase the top layer hiding the image or information. Thus, the percentage of students with the necessary for our study high level of information and digital competence was - 7\% of the total number of participants.

Further, according to the results of the questionnaire, we identified a group of students who know the proposed technologies at an above-average level. Thus, these students know and are able to create websites, pages, maintain blogs and use a number of platforms with elements of programming certain game material - about $72 \%$ of respondents (43 people). Nevertheless, the clarifying and leading questions during the interview showed that some respondents «did not quite understand the question»; "decided that the use of websites in the Internet»; "subscribe to a channel», proposed in the list of platforms etc. Is also a process of creation - the number of people with an average level of information and digital competence was not more than $47 \%$ of the whole group of respondents (15 people dropped out).

We also noted that $12 \%$ of the respondents could not pass the questionnaire and confirmed a low level of proficiency in this competence. Later on, we included five more respondents to this group, who were excluded from the group with an average level after the interview. This group in the subsequent work also required more attention to the details of the proposed work, the inclusion of additional time to demonstrate the principles of work and the algorithm of action.

Based on the analysis of the questionnaire and the results of the interview, the sufficient level of information and digital competence was 27\% (16 people).

Our further work consisted in taking participants through a web quest based on the basic theory of the disciplines of the inclusive cycle. The important thing for us in using this type of work was that we were not limited in educational resources; there was a connection of educational material with real life. The greatest emphasis, as in other studies of the scientific community, was on the active involvement of students in research activities, and the role of the teacher was advisory in nature [13].

After the respondents passed the web quest, a two-part questionnaire on the results awaited them. The first component allowed us to consider the emotional state, and the second component allowed us to consider the students' readiness to try their hand at creating a web quest and shaping their programming skills.

It is important to note that students under the age of 25 had no problems with connecting, setting up and going through the web materials offered. Whereas the students of the older group - working professionals, who receive additional specialty quite often, had difficulties from connecting to the interactive whiteboards to sending Google Forms during the web quiz (15\% of participants). This aspect not only influenced the changes in the educational process in the direction of increasing the time to explain the technical features of the work, but also made it clear that the status of one or another respondent in the eyes of the modern student is quite low. In addition, this 
«status» will be impossible to «roll back» when we return to the usual standards of offline education.

Thus, based on our findings, we conclude that the most significant and requiring attention to the problems of implementation and use of such technologies in the daily practice of non-technical professionals - teachers are:

- Insufficient training of already working professionals to take advantage of web technologies and multimedia systems;

- «Lack of interest» in the development in the direction of interactive work online without specially created conditions;

- Rather «superficial» basic educational programs in the training of non-technical specialists in the formation of information and digital competence;

- Lack of incentives to «spend time» on additional courses or methodological developments to improve qualifications, even after training at the university or in non-medical areas of MES

- Low level of material and technical support, especially with regard to the use of special technologies to support the educational process for children with developmental disabilities.

\section{CONCLUSIONS}

Of course, this is only part of the modern challenges for specialists in pedagogy, special and remedial, primary and preschool education, but at the same time - it is an opportunity to review existing practices, adapt materials for online work and improve the quality of education as professionals themselves, and their wards. Since the experiment is ongoing, we cannot reveal in more detail all the aspects of our data, to present partially worked out by the students themselves interactive games and other types of interaction developed in the process of classroom and independent work. But, at the same time it is worth noting that some of the students already use the created developments in their daily or educational practice, which has a rather strong impact on the «authority» of the teacher in the eyes of children.

\section{REFERENCES}

[1] M. Hryshchenko, L. Hrynevych, O. Elkin, S. Kalashnikova, I. Kobernyk, V. Kovtunets, O. Makarenko, O. Malakhova, T. Nanaieva, G. Usatenko, P. Khobzei, R. Shyian, Nova Ukrainska Shkola: Kontseptualni zasady reformuvannia serednoi shkoly, Ministerstvo Osvity i Nauky Ukrainy, 2016.

[2] L. Qingsong, The application of multimedia technology in web education, Physics Procedia, 2012, 33, 1553-1557.
[3] C. C. C. Lam,. L. U. I. Tou, Making education fun! The marketing of advanced topics by multimedia, Procedia-Social and Behavioral Sciences, 2014, 148, 79-86.

[4] C. A. Knoop-van Campen, E. Segers, L. Verhoeven, Effects of audio support on multimedia learning processes and outcomes in students with dyslexia, Computers \& Education, 2020, 150, 103858.

[5] M. A. Lindner, A. Eitel, J. Barenthien, O. Köller, An integrative study on learning and testing with multimedia: Effects on students' performance and metacognition, Learning and Instruction, 2018, 101100.

[6] T. M. Khan, The effects of multimedia learning on children with different special education needs, Procedia-Social and Behavioral Sciences, 2010, 2(2), 4341-4345.

[7] M. D. Abdulrahaman, N. Faruk, A. A. Oloyede, N. T. SurajudeenBakinde, L. A. Olawoyin, O. V. Mejabi, ... \& A. L. Azeez, Multimedia tool $\mathrm{s}$ in the teaching and learning processes: A systematic review, Heliyon, 2020, 6(11), e05312.

[8] A. Khilya, A. V. Korol, Features of the use of ICT in Speech Therapy Practice of Preschool Institutions, Society. Integration. Education - SIE-2021, 2021.

[9] N. V. Olkhova, Robocha prohrama vybirkovoi navchalnoi dystsypliny pidhotovky bakalavra (na bazi dyploma molodshyi spetsialist) haluz 0101 Pedahohichna osvita napriamu 6.010102 Pochatkova osvita: Informatsiino-komunikatsiini tekhnolohii u pochatkovii shkoli, Skhidnoievropeiskyi natsionalnyi universytet imeni Lesi Ukrainky, Lutsk, 2015.

[10] T. A. Makhynia, Robocha prohrama navchalnoi dystsypliny «Informatsiini tekhnolohii navchannia v spetsialnii osviti» za vilnym vyborom zdobuvacha vyshchoi osvity skladena vidpovidno do navchalnykh planiv osvitno-profesiinykh/osvitno-naukovykh prohram Navchalno-naukovoho instytutu menedzhmentu ta psykholohii DZVO «Universytet menedzhmentu osvity», Kyiv, 2019.

[11] S. V. Chupakhina, Robocha prohrama «IT u inkliuzyvnii osviti ditei z uskladnenniamy protsesiv rozvytku i sotsializatsii» dlia zdobuvachiv pershoho (bakalavrskoho) rivnia vyshchoi osvity za spetsialnistiu 012 Doshkilna osvita, DVNZ «Prykarpatskyi natsionalnyi universytet imeni Vasylia Stefanyka», IvanoFrankivsk, 2019.

[12] M. Yu. Kademiia, L. S. Shevchenko, A. P. Kobysia, S. S. Kizim, S. Yu. Liulchak, Robocha prohrama oboviazkovoi navchalnoi dystsypliny «Informatsiino-komunikatsiini tekhnolohii v naukovykh doslidzhenniakh» dlia studentiv stupenia vyshchoi osvity mahistr za haluziamy znan 01 Osvita / Pedahohika, 02 Kultura i mystetstvo, 03 Humanitarni nauky, 05 Sotsialni ta povedinkovi nauky, 06 Zhurnalistyka, 07 Upravlinnia ta administruvannia, 09 Biolohiia, 10 Pryrodnychi nauky, 11 Matematyka ta statystyka, 22 Okhorona zdorovia, Vinnytskyi derzhavnyi pedahohichnyi universytet imeni Mykhaila Kotsiubynskoho, Vinnytsia, 2019.

[13] E. Zhestkova, D. Gusev, N. Kudakova, E. Gubanihina, E. Klyueva, F. Povshednaya, Web-Qwest as a Form of Organization of Independent Work of Students, In ENVIRONMENT. TECHNOLOGIES. RESOURCES. Proceedings of the International Scientific and Practical Conference, 2019, Vol. 2, pp. 259-263. 